\title{
Bread-and-butter or exotica?
}

A Chorce trio gave details of the Labour Government's new Ministry of Technology at a Millbank Tower press conference in November 1964Frank Cousins, trade union leader turned minister; C. P. Snow the author, alias Lord Snow, a junior minister; and Professor P. M. S. Blackett, deputy chairman of the minister's Technology Advisory Council. Dr Ieuan Maddock at that time was with the Atomic Energy Authority at Aldermaston. The following September he moved over to Mintech at the invitation of Dr John Adams to help get the fledgling ministry moving.

At the end of last month, six ministers and two ministries later, Sir Ieuan Maddock, FRS retired as Chief Scientist at the Department of Industry. He remains acting director of the National Physical Laboratory.

A tough, ebullient Welshman, he had needed both toughness and ebullience to steer industry and government research establishments towards what he saw as the right kinds of technology. In the process he offended both high-technology industry and the establishments: he was bruised by the expediency of politicians.

The concept of Mintech had been generated primarily by Blackett, who knew at first hand how science had been harnessed to immediate national objectives during the 1939-45 war and who believed that industry could now be regenerated by a similar approach. Maddock joined Mintech as a deputy controller. It was then a very small ministry, responsible for only four industries-electronics, computers, telecommunications and machine tools. Mintech expanded with the transfer of the engineering industry divisions of the Board of Trade in February 1966 and Maddock went on to head five industrial divisions.

Mintech also broadened in scope to deal with basic industrial structures, not just technology. One facet of this approach led to the setting-up of ICL as Britain's national computer company. Various other programmes were mounted to stimulate the application of advanced machines and techniques in industry. "By the summer of 1969", Sir Ieuan recalls, "we were really beginning to get results".

Then came a body-blow-the change of government in 1970 which abolished Mintech and put its initiatives into reverse. "The new government classified everything we were trying to do at Mintech as 'interventionist'. The shutters came down absolutely and completely. You were guilty until you could prove yourself innocent. A lot of schemes were scrapped long before we had a chance of finding out whether they were good or bad".

In his work as Controller of Industrial Technology at the new Department of Trade and Industry (DTI), Maddock was becoming more of an administrator, working on, among other things, the future of the steel industry. "By that time I had moved a fairly long way away from science and technology". This was rectified in February 1971, when he was appointed to the new post of Chief Scientist at the Department. $\mathrm{He}$ was to be responsible for the general strategy and coordination of the Department's research activities, while retaining his responsibilities for the DTI sponsorship of the steel, electronics and computer industries.

"At that time", Sir Ieuan says, "I found it personally very difficult. I was dedicated to what we had been doing at Mintech and I was seeing it dismantled. I was having to fight rearguard actions all the way, saying 'Look, you're throwing all kinds of babies away with the bathwater'and subsequent events proved that to be right.

"I have to confess I didn't enjoy that part of my life at all. In nearly 40 years of government service it is the only period I can recall when I was really pretty unhappy with my environment".

Fresh air blew in with the Rothschild proposals, fully supported by Maddock, which introduced the customer-contractor principle into government R\&D spending. "With the dip in my moral factor at that time", Sir Ieuan says, "this gave me something to get my teeth into".

The DTI itself was not a customer department, in the way that Defence was; how should the Rothschild principles be applied? Maddock's solution was to set up a group of industry-government research requirements boards to act as proxy customers, decide priorities and allocate funds. As their programmes came under scrutiny from the boards, the government laboratories hated

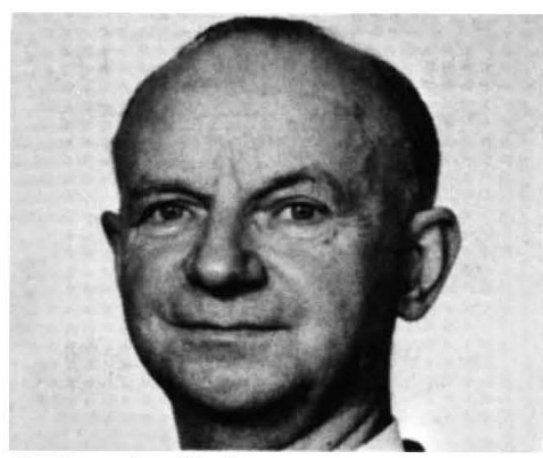

Sir Ieuan Maddock

the whole exercise, Sir Ieuan admits cheerfully. The balance of R\&D spending changed, with less being channelled through the establishments and more through the research associations (and through industry).

On public occasions throughout his time at Mintech, DTI and DoI, Sir Ieuan has repeatedly stressed the importance of the bread-and-butter industries and the dangers of pursuing high-technology exotica. The transfer of existing technologies is more important than the creation of new ones; this has become his personal crusade.

"It's not so much the money, it's where you address the best intellects", he says. "The staff list at Harwell in about 1954 contained the cream of the cream; what a hell of a risk that was". The best Japanese brains, meanwhile, were going into the engineering and manufacturing industries. "That's why they're knockhell out of us now".

Thus Sir Ieuan finds himself "a bit of a renegade" on the Joint European Torus, because "if JET comes to Britain it's going to suck in another new generation of cream talent"talent that is sorely needed in the engineering industries.

During his time at the three ministries, Sir Ieuan has worked with seven ministers: Cousins, Benn, Rippon, Davies, Walker, Benn again and Varley. His most stimulating time was at Mintech, working with Benn as minister and the formidable $\mathrm{Sir}$ Richard (Otto) Clarke as Permanent Secretary.

He quotes two main overall conclusions. First, the tragedy of $\mathbf{1 9 7 0}$ when promising Mintech projects were killed off indiscriminately; clearly this still hurts. Secondly, the fact that all the various microeconomic attacks on particular industrial problems will be of little benefit without a stable, healthy macroeconomic background. "Unless you've got that", he says, "technology will not flow". 